\title{
Meditações de uma crítica missionária
}

\section{Meditations of a missionary critic}

\section{Valmir Jesus dos Santos}

Valmir Jesus dos Santos

Doutorando do Programa de Pós-Graduação em Artes Cênicas pela Escola de Comunicações e Artes da Universidade de São Paulo (ECA-USP).

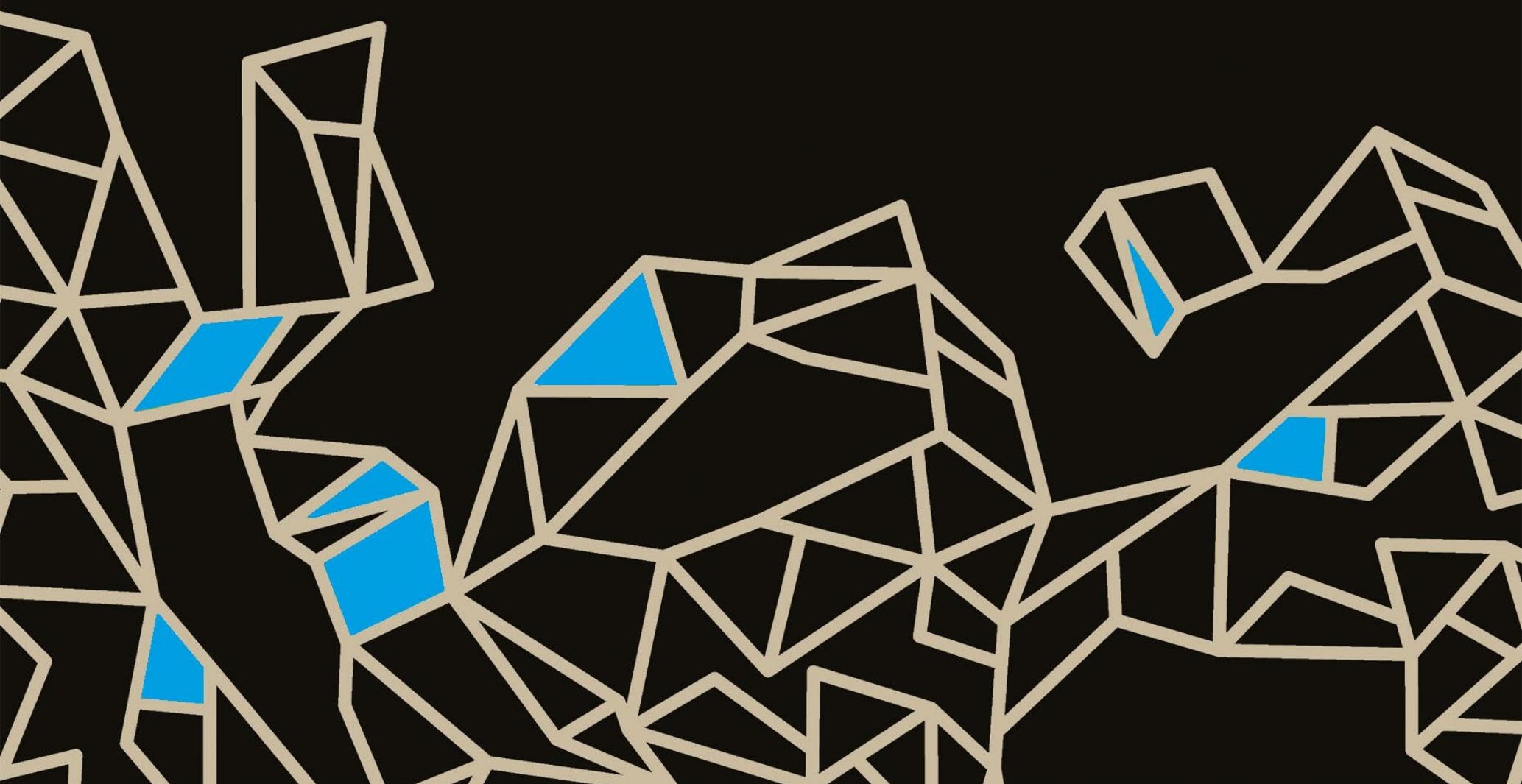




\section{Resumo}

O artigo coteja a primeira e a última crítica de Mariangela Alves de Lima escritas a partir de espetáculos do Teatro Oficina Uzyna Uzona, Gracias, señor, de 1972, e Macumba antropófaga urbana de SamPã, de 2011. Aponta especificidades acerca dos procedimentos estéticos e das ideias do ofício praticado durante 39 anos no jornal O Estado de S. Paulo, em que ocupou a função de seu professor, Sábato Magaldi. A análise continuada das fases do grupo dirigido por José Celso Martinez Corrêa imprimiu perspectiva histórica desde o pior momento da ditadura civilmilitar, passando por redemocratização, implantação da moeda oficial vigente e governos à esquerda do espectro político.

Palavras-chave: Teatro, Crítica teatral, Mariangela Alves de Lima, Teatro Oficina.

\section{Abastract}

This article compares the first and last theater reviews by Mariangela Alves de Lima about the plays of the Teatro Oficina Uzyna Uzona, Gracias, señor, from 1972, and Macumba antropófaga urbana de SamPã, from 2011. It points out specificities about the aesthetic procedures and the ideas of the profession practiced for 39 years in the newspaper $O$ Estado de S. Paulo, in which she held the position of her teacher Sábato Magaldi. A continuous analysis of the phases of the group led by José Celso Martinez Corrêa printed a historical perspective from the worst moment of the civil-military dictatorship, including redemocratization, the implementation of the current official currency and governments to the left of the political spectrum.

Keywords: Theatre, Theatrical criticism, Mariangela Alves de Lima, Teatro Oficina.

Expressar-se a partir do trabalho do outro é uma das condicionantes da prática da crítica de arte, seja nas frentes jornalísticas ou acadêmicas. Quando artistas e espectadores-críticos constroem longevidade, conforme a natureza de seus trabalhos, deixam mais nítidas as decantações em termos de linguagem e de ofício. As produções artísticas e intelectuais, de lado a lado, permitem divisar pesos e contrapesos nos processos de concepção e 
de recepção. A exemplo do que é possível aferir nos 39 anos em que Mariangela Alves de Lima e Teatro Oficina Uzyna Uzona exerceram alteridades parelhas. Ela, principalmente por meio das páginas de O Estado de S. Paulo. O grupo, por meio dos espetáculos criados coletivamente ou dirigidos por José Celso Martinez Corrêa.

O primeiro encontro se deu na forma de um "esbarrão", como o diretor guardou na memória a presença da crítica de 24 anos na plateia, ou meIhor, na "assembleia", conforme designava a tentativa de se colocar no mesmo ângulo de visão do seu espectador em Gracias señor ${ }^{1}$, em maio de $1972^{2}$, obra dividida em duas partes, apresentadas em noites intercaladas.

A subterrânea sala Gil Vicente, do Teatro Ruth Escobar ${ }^{3}$, ainda trazia reminiscências da intervenção arquitetônica da montagem de $O$ balcão, por Victor Garcia e texto de Jean Genet, de 1969. Não havia poltronas na sala de apresentação de pé-direito alto. Na parede ao fundo do palco, ainda era possível ver tijolos quebrados. Um sugestivo ambiente em ruínas que a cenógrafa Lina Bo Bardi assumiu como tradução do beco sem saída do Brasil sob ditadura civil-militar, que redobrara métodos de violência após decretar o Ato Institucional no 5 (Al-5), havia pouco mais de dois anos ${ }^{4}$.

Mariangela Alves de Lima atuava no primeiro ano como colaboradora de O Estado de S. Paulo e cumpria o derradeiro ano do curso de crítica teatral na Escola de Comunicações e Artes da Universidade de São Paulo (ECA-USP).

O choque físico na imagem descrita por Corrêa - nascido em Araraquara a 30 de março de 1937 - serve como metáfora do momento histórico-político.

1 Adotamos a grafia com vírgula, Gracias, señor, apesar de constar sem em parte do material gráfico, de anúncios e textos jornalísticos da época. Quem sabe a supressão do sinal traduza, inconscientemente, o quão urgiam os tempos nos anos de chumbo.

2 A temporada paulista de Gracias, señor teve pré-estreias em 25 e 26 de abril e estreou em 27 de abril de 1972, na sala Gil Vicente do Teatro Ruth Escobar. Espetáculo dividido em duas partes com sessões intercaladas de terça a domingo. A temporada carioca estreou em 3 de fevereiro de 1972, no Teatro Teresa Rachel, com apresentação integral por noite e duração de cerca de quatro horas.

3 Localizado à rua dos Ingleses, 209, no bairro da Bela Vista, o popular Bixiga, onde o Oficina levou Roda viva em 1968, espetáculo alvo de agentes paramilitares do Centro de Caça aos Comunistas, o CCC, que espancaram atores numa sessão. No mesmo ano, esse teatro abrigou a Primeira Feira Paulista de Opinião, organizada pelo Teatro de Arena e dirigida por Augusto Boal com numerosa participação de artistas instigados a responder à provocação: "O que pensa você do Brasil de hoje?".

4 Sob o governo do general Emílio Garrastazu Médici (Arena), de 1969 a 1974, o mais radical na repressão policial-militar aos opositores da ditadura. 
Esteticamente, o Oficina se empenhava no enfrentamento à repressão política. Surgido em 1958, o grupo se questionava a respeito da relação com o público e revisava as próprias escolhas formais e temáticas após o primeiro decênio profissional (1961-1971). Por outro lado, a crítica nascida em São Paulo a 6 de julho de 1947, no bairro da Bela Vista, e cuja família migrou para Piracicaba (SP) quando tinha cerca de seis anos, veio a residir e morar na capital em 1967, aos 20 anos, para estudar. A jovem que ingressara em jornalismo na ECA e, depois, transferiu-se para o curso de crítica teatral, na mesma escola, fora chacoalhada pela postura engajada do trabalho antiespetacular que propunha atitudes que hoje seriam lidas como ativistas ante o autoritarismo. O Oficina radicalizava no "teatro agressivo", como cunhou Anatol Rosenfeld (1996, p. 45) referindo-se a outras peças recentes, estudioso refratário à "ira recalcada" (Ibid., p. 51) de Corrêa, "expoente virulento desse tipo de teatro" (Ibid., p. 46).

Apesar da esquiva ${ }^{5}$, o crítico e ensaísta alemão, então radicado no Brasil, reconhecia nas criações do núcleo um reflexo do "sentimento de urgência". Especialmente após O rei da vela, em 1967, texto de Oswald de Andrade, passando por Roda viva, em 1968, de Chico Buarque; e Galileu Galilei, no mesmo ano, de Bertolt Brecht. Todas - nunca é demais reforçar - encenadas durante o período de exceção que não tardou a adotar a tortura como política de Estado.

Portanto foi nesse ambiente de impasses e inconformismos que Lima e Oficina passaram a contracenar em suas trajetórias. "Mais que amor à primeira vista, com Mariangela senti no nosso primeiro encontro, na cena, atuando em Gracias señor, a comunhão de uma irmã animal que buscava naqueles tempos de escuridão a Luz onde quer que ela se encontrasse", anotou Corrêa (2011) em seu blog, na peculiar escrita performativa, por ocasião do desligamento de Lima do centenário O Estado de S. Paulo, em 2011, após 39 anos de colaboração continuada, desde 1972. Ele descreveu que topou com ela "na parte além da Morte do desejo reprimido, na Barca de Serafim, no Sonho

5 "Reconhecer a eventual viabilidade estética de um teatro agressivo e violento, assim como os motivos frequentemente justos da sua manifestação, não implica acreditar, desde logo, no seu valor geral e na sua eficácia necessária, no sentido de abalar o conformismo de amplas parcelas do público. [...] O mérito de José Celso no terreno artístico é indiscutível. Mas fazer da violência o princípio supremo, em vez de apenas elemento num contexto estético válido, afigura-se contraditório e irracional" (ROSENFELD, 1996, p. 55-56). 
da União dos Corpos, na Orgya" (Ibid.), ilustrando alguns dos sete movimentos do espetáculo. "Senti que estava diante de uma sensitiva. Mariangela, uma jovem de 24 anos, estava em transe lúcido: tremia, tinha os olhos transbordantes d'águas e um vermelho vinho vibrava vivo em todo seu Corpo" (Ibid.).

Gracias, señor é eixo deste artigo por demarcar, corpo a corpo, o princípio do trajeto de quase quatro décadas em que Lima analisou espetáculos do então autonomeado Grupo Oficina Brasil e, consequentemente, as ideias de seu diretor até Macumba antropófaga urbana de SamPã, de $2011^{6}$, na fase do atual Teatro Oficina Uzyna Uzona. A primeira crítica publicada, contudo, não saiu no jornal em que colaborava, mas na revista Estudos Cebrap, do Centro Brasileiro de Análise e Planejamento, instituição surgida em 1969 por iniciativa de professores de diferentes áreas afastados das universidades em razão da ditadura militar e dispostos a articular um espaço de produção de conhecimento crítico e independente (LIMA, 1972).

A última anista do bacharelado de crítica teatral - que durava três anos e cujo diploma jamais retirou - já exprimia o pendor sociológico e a ambição filosófica de uma escrita de cunho ensaístico. "Pode o teatro transmitir ao público uma consciência teórica?” (Ibid., p. 149), perguntou, logo na primeira linha. $E$ respondeu mais adiante que não se tratava de discutir teoricamente o teatro, mas o presente do espectador impactado pelos pressupostos de uma criação que confronta o público e coloca seus próprios criadores em xeque, bem como a arte que a veicula, o teatro. "Desta vez não se trata de inauguração de um estilo, de outro tropicalismo" (LIMA, 1972, p. 153), considerou, aludindo às veias oswaldianas que alimentaram o "estado anímico de inquietação e insegurança" (Ibid., p. 153) que pairava na sala de apresentação. No decorrer da peça-manifesto, "o espectador sabe que a qualquer momento pode ser solicitado para uma participação. E que será forçado a utilizar não só a situação de estar-no-teatro, como toda a experiência de vida que o conduziu até esse lugar" (Ibid., p. 153).

6 A primeira temporada de Macumba antropófaga urbana de SamPã estreou no Teatro Oficina em 16 agosto de 2011. A produção preferia o termo "macumba" a "espetáculo" para definir o trabalho que marcou os 50 anos do Oficina e articulava performances, um banquete e uma caminhada pelo Bixiga. 
Com gesto iniciático focado na proposição artística transgressora, estruturada para "motivar inconscientemente a uma participação de endosso ou agressão" (LIMA, 1972, p. 150), seu texto acabou representando, involuntariamente, papel contemporizador ao construir uma abordagem reflexiva não reativa, distinta da polêmica que enredou seu professor e espécie de mentor, Sábato Magaldi, e o ator, diretor e cofundador do Oficina, a propósito de Gracias señor. Lidas 48 anos depois, a sequência composta de crítica, réplica e tréplica foi das mais violentas na historiografia das artes da cena no país. Não chegaram a embate físico, mas a virulência textual deixou sequelas indeléveis.

Magaldi assistiu às duas noites de pré-estreia, destinadas ao público majoritariamente universitário. Sua análise no Jornal da Tarde (MAGALDI, 1972) emitiu sinais premonitórios. Argumentou que aceitar ou recusar o espetáculo Gracias, señor implicava correr "o risco de debater o problema proposto fora dos limites da 'sessão de teatro', convertendo-o numa polêmica sobre dramas existenciais, métodos políticos e sistemas de encenação" (STEEN, 2014, p. 248). Reiterou respeito e admiração pelo conjunto. Lembrou da relevância de produções recentes, como Galileu Galilei e Na selva das cidades. Em sua visão, “o Oficina queria fazer 'te-ato' e fez teatro, só que frequentemente mau teatro" (Ibid., p. 248). Destacou a contradição do discurso do grupo em romper com procedimentos convencionais de criar e de produzir, porém redundá-los ao cumprir temporada em endereço do circuito comercial e cobrar ingresso como qualquer outra produção em cartaz na cidade. "Para ser autêntica, a 'sessão de te-ato' deveria chegar ao happening total, com todas as consequências" (Ibid., p. 248), cobrou, deduzindo que "o tiro saiu pela culatra" (Ibid., p. 248):

Fica, então, uma caricatura da verdade, preenchida por todas as baboseiras da moda no teatro de vanguarda, inspiradas em grande parte no arsenal das teorias irracionalistas: contato sensorial, desafio pelo fluído do olhar, suposta captação de energias e uma comunhão estancada pelas exigências dos chamados bons costumes (qualquer baile de Carnaval é mais autêntico do que a festa improvisada no palco). O "te-ato" se transforma numa repressão ao teatro. (STEEN, 2014, p. 248-249)

Dias depois, o Oficina divulgou aos espectadores sua Carta aberta ao Sábato Magaldi, também servindo para outros, mas principalmente destinada aos que querem ver com os olhos livres (STAAL, 1998, p. 195), assinada 
pelo grupo, não datada, e mais uma vez tributária de Oswald de Andrade ao mencionar indiretamente o Manifesto da poesia pau-brasil: "Nenhuma fórmula para a expressão contemporânea do mundo. Ver com os olhos livres" (Ibid., p. 208). Em meio às treze páginas de sulfite, lembrou-se de que, apesar do cinquentenário da Semana de Arte Moderna, a cidade ainda convivia com uma "tradição intelectual estranha" (Ibid., p. 195), a "chamada intelligentsia paulista" (Ibid., p. 195), a saber:

pessoas que se entregam à atividade cultural e ao compromisso do "caminho certo", político-abstrato, com leis muito próprias, uma coisa muito distante da inteligência e muito próxima da racionalização de uma neurose de não-criação artística e de não-criação de ação política. Uma couraça de seriedade cultural, de sensibilidade árida; de racionalismo reduzido a três ou quatro fórmulas. (STAAL, 1998, p. 195)

É preciso contextualizar que Gracias, señor era um experimento movido pelo clamor de transformações candentes nos planos da vida nacional, do sujeito e da coletividade. Desejava provocar a consciência crítica perante as garras do sistema político que concentrava o poder. Aprofundar sendas que montagens anteriores abriram de maneira histórica. Esse processo de autocrítica levou seus integrantes a identificar limites e a ambicionar ultrapassá-los. Revisões, decerto, influenciadas pelo contato com os grupos estadunidense Living Theatre e argentino Los Lobos. O Oficina os acolheu em 1970 com vistas a um trabalho comum. Todavia não vingou a prospecção junto àqueles que eram alguns dos expoentes da vanguarda experimental à época e para os quais a frontalidade da cena não rimava com passividade de quem a assiste. "O Teatro se transforma numa assembleia permanente de discussões mas, no fim do ano, por falta de acordo, a associação triangular se desfaz" (STAAL, 1998, p. 332). Restou impregnado o modo de criação coletiva.

No ano seguinte, 1971, o Oficina fez turnê com repertório pelas regiões Nordeste e Centro-Oeste, ocasião em que seus artistas empreenderam um espírito expedicionário por novas maneiras de interagir com o público: da classe média ou universitária de Brasília a moradores não iniciados nessa arte em rincões da Bahia ou de Pernambuco. Daí a determinação em cruzar a instância do novo: "O novo não tem espectadores, não tem críticos" 
(Ibid., p. 199), vaticinou o coletivo replicante no documento dirigido a Magaldi. "Nesse trabalho, não estamos apenas nos discutindo. Estamos nos discutindo e discutindo nosso público e nossos críticos. Não estamos nos discutindo enquanto função social, mas todas as funções sociais correlatas" (Ibid., p. 199). O escudo da terceira pessoa não ocultou o DNA zecelsiano da escrita. "Nesse trabalho operamos uma paralisação de toda a nossa atividade para interrogar a nossa função de filhos prediletos" (Ibid., p. 199). Sob tal ímpeto desbravador, a carta escala o plano pessoal do destinatário:

Olhe, Sábato, a única maneira de você escrever sobre esse trabalho era fazendo uma viagem na tua função social de crítico. Pois lá, na sala onde você esteve não estando, era só nisso que pensávamos quando te olhávamos. Era na pessoa atrás do terno e gravata e da risada de sala de visitas mineira. Nós o amamos muito naquele momento e sentimos todas as suas couraças, mas você não quis deixar o seu dever profissional o tiro saiu pela culatra...

Você fez a crítica de um espetáculo em que ela não cabe. Você não viu Gracias, señor.

Você não viu porque essa crítica que você está fazendo para esse trabaIho não é mais crítica, é censura, podes crer. (Ibid., p. 202)

Ao que Magaldi devolveu na mesma moeda em sua tréplica, mas, em princípio, evitou o espalhafato. Pelo menos tentou. Inicialmente, fez a resposta chegar a amigos e pessoas do meio teatral. Tempos depois, encontrou Corrêa em um restaurante e este o cumprimentou como se nada tivesse acontecido. A refrega voltou à praça 26 anos depois, em 1998, com o lançamento do livro Primeiro ato: cadernos, depoimento, entrevistas (1958-1974), organizado por Ana Helena Camargo de Staal, sobrinha do diretor. A obra que compreende memórias desde a fundação da companhia até o exílio de seu líder em Portugal e outros países (1974-1978) - após ter sido censurado, preso e torturado por cerca de um mês - trouxe a íntegra da carta a Magaldi sem, no entanto, o acompanhamento da respectiva crítica, a não ser trechos. O crítico, então, republicou aquela resposta que circulara em pequeno circuito, dessa vez no livro Depois do espetáculo, de 2003, intitulada Resposta a uma agressão. "E o faço como um rompimento definitivo" (MAGALDI, 2003, p. 304), indignou-se. "Não tenho o hábito de misturar problemas pessoais com valores 
artísticos: fiz restrições a um espetáculo de José Celso, mas sempre o considerei excelente diretor" (Ibid., p. 304); "E, a um golpe que se recebe, só cabe revidar com outro golpe" (Ibid., p. 304).

Assim, pouco mais de um quarto de século depois, o verbo revolveu brasas que se pensava adormecidas. O crítico alegou que se Corrêa tivesse se limitado "a recusar minha crítica, opondo-Ihe argumentos estéticos, eu silenciaria" (Ibid., p. 304). "Só achei que não poderia permanecer calado porque estavam em jogo princípios mais amplos, de que eu não abdicaria. Aceitar o juízo sobre a minha pessoa, e não apenas sobre um determinado comentário, seria demitir-me de uma dignidade elementar" (Ibid., p. 304). Cristalizou-se o rancor. Na capital paulista e no país sob recrudescimento de assassinatos de homens e mulheres engajados na luta contra o regime opressor, um crítico e um grupo de teatro, por meio de seu diretor, acusaram-se de práticas de intolerância.

Você, na Alemanha nazista, seria um Goebbels, como na União Soviética o decretador de uma linha única para a arte. Você nunca se interessou por saber o que fazem os seus colegas e, para sentir-se feliz e seguro na sua torre de marfim, rotula todos como representantes do teatro morto. (Ibid., p. 308)

Ou, por outra: "Você me pergunta se eu indago por que faço crítica, pra quê, pra quem?, e posso responder-lhe com honestidade que não faço outra coisa, como podem atestar-lhe meus alunos. Entretanto, você parece esquecer de perguntar-se por que tantos artistas de valor não estão mais a seu lado (Ibid., p. 309). A publicização redimensionou a intensidade do atrito, a ponto de Magaldi definir a carta do Oficina como "um testemunho do mau caráter de José Celso" (Ibid., p. 310). Numa das passagens, a tréplica virou um libelo pedagógico:

Procuro formar cidadãos livres, que pensam e escrevem pelas próprias cabeças e frequentemente emitem opiniões contrárias às minhas - que compreendo, respeito e estimulo porque acredito na diversidade, que tanto assusta José Celso. É ele quem deseja a submissão - e felizmente não consegue, porque a juventude está madura para repeli-la. (Ibid., p. 310) 
Sob esse fogo cruzado, a aluna, espectadora e crítica iniciante Mariangela Alves de Lima lançou seu olhar sobre o objeto do conflito de ideias e ofensas entre Magaldi e Oficina. Sua crítica a Gracias, señor em Estudos Cebrap, no segundo semestre de 1972, sondou os fenômenos teatral e político conjugados pelos criadores a partir das respostas comportamentais e emotivas às quais a audiência era estimulada. Feito "um laboratório de amostragem da nossa pequena burguesia. Nossos pequenos burgueses esclarecidos, sintonizados com a vanguarda teatral" (LIMA, 1972, p. 151). E derivou para uma ilação de tons behavioristas e biológicos: "Se a reação pode começar pela célula, Gracias, señor mostra a ineficiência da célula diante da compacta tessitura do organismo completo. A menos que essa célula esteja separada para ligar-se até a confecção de um outro tipo de tecido, resistente e amplo como seu opositor" (Ibid., p. 151), qual seja, o "mestre-sistema" (Ibid., p. 149) que pressiona e pede "obediência absoluta" (Ibid., p. 149).

Às questões levantadas pelos artistas em cena - "O que fazemos no teatro? Como? Por quê? Para quem?" (Ibid., p. 152), a autora ressalvou "uma certa margem de previsibilidade nas respostas do público" (Ibid., p. 152). Para tanto, ponderou:

Perguntar a esse público o que faz no teatro é mais que uma investigação sobre a finalidade da arte. É questionar um momento determinado da vida dessas pessoas. Não se trata de discutir teoricamente o teatro, mas discutir o presente do espectador, o que está acontecendo em uma noite de lazer ou de cultura. (LIMA, 1972, p. 152-153)

Em artigo no qual dissertava sobre o fazer crítico, 33 anos depois, Lima acercou-se do universo do divã, como se moderasse uma escuta atemporal entre o professor e o grupo que a influenciaram sobremaneira. "Para apaziguar a consciência dos críticos a era pós-freudiana revelou, entre outras coisas, a 'objetividade da subjetividade' poupando-Ihes o trabalho de arquitetar estéticas normativas destinadas ao repúdio" (Id., 2005, p. 22). Aproximou quem escreve de quem assiste ao espetáculo, ombro a ombro. "Ambos trazem para a sala de espetáculo suas experiências pessoais, suas limitações físicas e emocionais, suas preferências e couraças íntimas que os tornam incapazes de usufruir determinados aspectos da manifestação teatral" (Ibid., p. 22). 
Numa análise motivada pelos dez anos da geração que retomou as atividades do grupo e do teatro até os dias de hoje, a partir de Ham-Let, criação de 1993 - geração da qual o ator e diretor Marcelo Drummond é um dos pilares -, Lima comentou que "o Oficina aprendeu a instrumentalizar a história para não curtir saudade ou mágoa".

Há que considerar ainda o pêndulo ideológico nas entrelinhas de cada escrito imbuído da missão de problematizar a experiência de contracenar com a obra viva. Afinal, qual a dificuldade em apreender o objeto artístico e não se deixar levar exclusivamente por esse viés? Isso oscila, reconheceu Lima:

O texto às vezes fica totalmente tendencioso porque tem uma empatia muito grande com o projeto artístico e você não sabe que está sendo tendencioso. E vice-versa, coisas fantásticas sobre as quais você tem repulsa porque contrariam o seu projeto, a sua visão de mundo, a sua ética. (SANTOS, 2018)

Na mesma entrevista, a autora lançou mão de bom humor tampouco raro em seus escritos. "Se bem que a direita raramente faz coisas boas. Do fundo do coração, eu acho a direita muito pior do ponto de vista estético, não tem vergonha nenhuma da sua caretice, da sua bobagem" (Ibid.). Corrêa, por seu turno, arguiu em seu diário de exílio, então na França, em 1977, que são "amedrontados" aqueles que não viram Gracias, señor e teriam divulgado "a lenda do espetáculo 'formalista e escapista'. Mas filmamos ${ }^{7}$ tudo e sei que um dia voltaremos a discutir sobre esse trabalho" (STAAL, 1998, p. 130).

Nesse diálogo intergeracional ora retraçado, Lima raciocinou e deu subsídios para situar os que vieram depois:

O Oficina, naturalmente, me formou também. A arte forma o seu crítico, essas coisas exponenciais que eu testemunhei fizeram a minha cabeça também. O Oficina ainda é um projeto ardente. A geração do Sábato teve dificuldades. O Oficina é sempre um teatro social, com os dedos voltados para o outro, para a alteridade, para o excluído, para o que está embaixo, sempre social e otimista, reconhecendo a força daquilo ali. O Décio compreendeu

7 Consta do acervo da Cinemateca Brasileira o filme Gracias, señor (1972, $16 \mathrm{~mm}, 20 \mathrm{~min}$ ), captado com três câmeras. Resultado de quatro horas de acompanhamento da realidade do espetáculo e da plateia. Levou um ano para ser montado. 
melhor o Oficina do que o Sábato, que ficava um pouco chocado com a falta de decoro, e que não era democrático para ele. (SANTOS, 2018)

Em 1983, quando a ditadura se arrefecia, Lima retomou Gracias, señor no ensaio Eu sou índio, publicado num dos livros da série de seminários $O$ nacional e popular na cultura brasileira8, com o subtítulo Teatro: o seu demônio é beato. Ela sistematizou a noção de público, a origem de classe do Oficina, a perspectiva histórica e as poéticas que eclodiram do processo criativo. Mesmo com as intermitências do trabalho nos últimos anos, dada a perseguição política e o exílio de Corrêa, a crítica infere que a "trajetória peculiar do grupo e a presença de uma liderança que praticamente determina essa trajetória, tornam o Oficina um caso à parte na evolução de um grupo teatral" (LIMA, 1983, p. 171). Singularidades que antevê como ação cultural conexa ao espaço público, aos pressupostos da arquitetura e do urbanismo no entorno do edifício-sede à rua Jaceguai, 520, tombado pelo Condephaat ${ }^{9}$ no ano anterior, 1982, como bem histórico.

Descobrindo a missão descobre-se também uma função do teatro que não é apenas a sua natureza, mas o que dele se espera como resultado: "A função do teatro - o verdadeiro papel do teatro - é levar o público para fora dos teatros.' E assim um grupo chega, depois de uma persistente investigação do seu próprio território cultural e social, à iniciativa de propor o abandono desse público. Em direção a outro grupo social e a outro espaço. (LIMA, 1982, p. 170).

Nos idos de 1970, em que confluíam contracultura e discursos heterodoxos, Lima (1984, p. 112) aprendeu com João Cabral de Melo Neto que "a palavra é mais do que uma ponte, é um ser no mundo". Descobriu com Victor Garcia e sua montagem de Cemitério de automóveis, com texto de Fernando Arrabal - e à qual assistiu treze vezes (MATE, 2006) -, que "é possível interferir num espetáculo e apropriar-se dele acrescentando novas associações ao que está em cena. Antes disso eu sabia apenas aceitar o que estava em

8 Os seminários em torno do tema $\mathrm{O}$ nacional e o popular na cultura brasileira foram realizados pelo Centro de Estudos e Pesquisas da Fundação Nacional de Artes, em 1980, sob coordenação de Adauto Novaes, abrangendo pesquisas nos campos da filosofia, música, literatura, artes plásticas, teatro, cinema e televisão.

9 Conselho de Defesa do Patrimônio Histórico, Arqueológico, Artístico e Turístico do Estado de São Paulo. 
cena e depois refletir laboriosamente em casa" (LIMA, 1984, p. 112). E constatou com Gracias, señor o lado sombrio da classe social à qual pertencia, a média, "e, principalmente, o quanto me pareço com ela" (Ibid., p. 112-113).

Ao completar sua quarta década, em 1998, o Oficina estreou Cacilda! e Lima notou que, "na plateia desconfortável e insólita da sua casa própria, espectadores encanecidos ombreiam com jovens" (Id., 1998, p. D7). Havia "uma geração que cresceu e amadureceu procurando no teatro alguma coisa que esse grupo nunca deixou de oferecer" (Ibid., p. D7). Recordouse do crítico francês Bernard Dort, que definiu como qualidade a vocação do Oficina para fazer um "teatro da insurreição" (Ibid, p. D7). Dort assistiu a O rei da vela em Nancy, na França, programada no Festival Mondial du Théâtre Universitaire, em abril de 1968. A peça também foi apresentada em Paris em 10 de maio de 1968, no icônico mês dos protestos estudantis que catalisaram a efervescência social.

\begin{abstract}
Mas talvez Brecht e Weill tenham ficado um pouco tímidos, um pouco prisioneiros do nosso bom gosto e de nossa tradição teatral ocidental. O Teatro Oficina foi mais longe: até à careta e à obscenidade. Esta comédia-farsa de um Brasil em transe é também uma maneira de terminar com a estéril imitação do teatro ocidental, de fazer tábua rasa. Estamos aqui diante não de uma tranquila tentativa de fundar um teatro folclórico e nacional (como era o espetáculo brasileiro apresentado em Nancy e Paris há dois anos atrás: Vide e morte severina) mas de um apelo raivoso e desesperado por um outro teatro: um teatro de insurreição. (PEIXOTO, 1982, p. 78)
\end{abstract}

Lima concorda com Dort: "De diferentes formas, nem sempre acertando na mosca, o grupo encarnou invariavelmente o lado inconformista da arte" (LIMA, 1998, p. D7). "Foi preciso mudar muito para preservar esse caráter insurreto. Propostas que, a seu tempo, significaram um desafio ao sistema político e aos costumes vigentes tornaram-se assimiláveis com o tempo" (Ibid., p. D7). O olhar da crítica em Cacilda!, de 1998, mostrou como o pensar retrospectivo tornou-se uma constante, evoluindo da "clareza ideológica dos programas artísticos" (Id., 1984, p. 110), quando "podia-se analisar o produto com o auxílio maternal e preciso da sociologia" (Ibid., p. 110), até a adesão a 
recursos de mediação tecnológica ${ }^{10}$, como apraz à teatralidade contemporânea, sem prejuízo dos fundamentos da coralidade.

O poder de atrito sempre foi essencial para a formulação da sua linguagem. Dessa forma, ao longo da história recente do País o Oficina criticou o servilismo da burguesia ao modelo estrangeiro, a ignorância da classe média, os desmandos da ditadura militar e a abulia erótica da civilização de consumo. Seu foco temático alterou-se a partir da observação direta dos fatos mais importantes da história social e do seu entorno. Como um teatro declaradamente de função social, as formalizações que adotou foram sempre enraizadas numa crítica da existência concreta. (Id., 1998, p. D7)

Na penúltima crítica publicada em $O$ Estado de $S$. Paulo ${ }^{11}$, a partir de Macumba antropófaga urbana de SamPã, de 2011, Lima reverbera o "esbarrão" em Gracias, señor com senso de síntese inventariante só alcançável por espectadores apaixonados ${ }^{12} \mathrm{e}$, aqui, continuados. A começar justamente pelo trajeto inicial do espetáculo baseado no Manifesto antropófago ${ }^{13}$, de Andrade. Criado para lembrar meio século do grupo, o trabalho ganhava as ruas em volta do teatro realizando um "cortejo formado por atores e público e os habitantes de um bairro que sustenta a maior escola de samba da cidade" (LIMA, 2011, p. D10). A abertura do texto entrega certo espírito juvenil da crítica e disponibilidade incondicional para percorrer mais da metade das três horas estimadas de apresentação. Ímpeto que, como ela sinaliza, guarda nexo com o costume de Aristóteles, que estimulava seus aprendizes a ter aula com ele andando, passeando.

$10 \mathrm{Em}$ seu site, o Oficina Uzyna Uzona lembra que foi pioneiro na transmissão ao vivo pela internet, em 2001, com as peças do Festival Teatro Oficina. Em 2007, transmitiu a gravação das cinco partes da transposição cênica do livro Os sertões, para registro em DVD. Disponível em: http://bit.ly/2Ne3IOe. Acesso em: 10 jan. 2021.

11 A última crítica de Mariangela Alves de Lima no jornal, no Caderno 2, intitulava-se "As faces da dor" (11 dez. 2011, p. D2), a partir do espetáculo Hécuba, dirigido por Gabriel Villela e com Walderez de Barros no elenco. A primeira crítica assinada no mesmo diário se deu a partir de Corpo a corpo, sob o título "Uma peça que faz o público pensar" (1ํ jan. 1972, p. 6), monólogo escrito por Oduvaldo Vianna Filho, dirigido por Antunes Filho e atuado por Juca de Oliveira.

12 Alusão à coletânea $O$ espectador apaixonado (Editora da UFRGS, 1962), com textos do diretor, dramaturgo e crítico italiano Ruggero Jacobbi.

13 Publicado na Revista de Antropofagia. São Paulo, ano I, n. I, maio 1928. 
Se a alegria é a prova dos nove, Macumba Antropófaga, espetáculo que encerra a temporada no Teatro Oficina, passaria pela prova com distinção e louvor. A moçada que se junta ao coro de intérpretes no desfile do espetáculo pelas ruas do Bexiga decorou a melodia e a letra das canções que acompanham o movimento peripatético e, mais do que isso, aprendeu o complexo arranjo que harmoniza as vozes do coral. Parte do público, e não a menor, está revisitando o espetáculo pelo prazer de participar e essa transformação da experiência singular em cerimônia ritual é um dos desejos explícitos de uma encenação que considera o teatro um lugar sagrado "que não pode ser vendido nem comprado". (Ibid., p. D10)

Sincronicamente, Gracias, señor mencionava o romance Serafim Ponte Grande, que Oswald de Andrade finalizou em 1928 e tornou-se bastante conhecido tanto pela construção refinada como pelo "prefácio incisivo que é ao mesmo tempo crítico e autocrítico" (FONSECA, 2008, p. 126). Nele, o autor desmantela a própria imagem e se declara "enojado de tudo" (ibid., p. 126). "Nesse prefácio, que é misto de manifesto e confissão, o escritor aponta erros por ele cometidos, decorrentes de sua falta de percepção da realidade como um todo" (Ibid., p. 126-127). O enredo cobre a vida errática do personagem-título até o desencantamento e sua morte após voltar de viagem à Europa. A criação coletiva cuja ideia era "oferecer simultaneamente a vivência e a reflexão" (LIMA, 1972, p. 151) incorporou uma cena chamada Barca de Serafim, espelhando o desencanto captado por Lima de maneira aguda naquele início dos anos 1970. "Dentro do panorama que o público delineia durante o espetáculo, Serafim não é mais possível. O homem só, revoltado contra a opressão, está condenado ao suicídio, jamais à liberação" (Ibid., p. 152)

Na mesma trilha do escritor modernista, um dos episódios de Macumba antropófaga urbana de SamPã era representado diante da antiga residência de Andrade na Bela Vista/Bixiga, mesmo bairro onde Lima nasceu. Nesse momento, "entra em cena uma cabrinha encarregada de ligar o poeta ao simbolismo da deglutição. É a bem-humorada colaboração de uma moradora do prédio que enriquece a trama convidando para a cena um gracioso e desinibido papagaio" (Id., 2011, p. D10). Minuciosa na descrição física do Teatro Oficina arquitetado por Lina Bo Bardi e Edson Elito, sempre que possível contracenando com o espaço inovador em suas análises, Lima reincidiu o tino observador ao seguir o cortejo asfalto adentro. No meio do caminho, ela leu: 
Algumas crianças aproveitam a oportunidade de exibir acrobacias e, acomodados nas mesas dos bares, estão também os críticos improvisados comentando isto ou aquilo. Enfim, nada de novo para cidades habituadas ao teatro de rua, mas, para os paulistanos, um formato teatral cada vez mais impossível em uma metrópole cujos espaços de convivência mínguam diariamente. Este é um dos sentidos que o Teatro Oficina Uzyna Uzona recria de modo vigoroso nesse trajeto inicial do espetáculo baseado no Manifesto Antropófago. O teatro para multidões deve invadir ruas, ser impregnado pelo que a rua oferece de modo distraído e deixar (se for bem-sucedido) um rastro fulgurante na memória dos espectadores ocasionais. (LIMA, 2011, p. D10)

A acurácia da autora se reveste da maleabilidade acumulada como observadora do repertório do Oficina ao longo da história. Seu modo de escrever também processa "devorações 'antropófogas"' (Ibid., p. D10). Vide como atenta à escuta das formas musicais do rap e do mangue beat fundidas em cena às "figuras dos intelectuais franceses que compreenderam e se enamoraram das civilizações indígenas e dos africanos desterrados no nosso território" (Ibid., p. D10). Mote para refazer a linha de tempo com o grupo e sugerir como Macumba antropófaga urbana de SamPã conversa com Gracias, señor, e vice-versa: "Em outras épocas, reverenciando o gênio tutelar da Antropofagia, os artistas do Oficina reafirmavam o caráter 'forte e vingativo' da nossa mescla cultural. Hoje exibem uma relativa serenidade para 'acreditar nos sinais, acreditar nos instrumentos e nas estrelas"' (Ibid., p. D10).

Publicado no último dia da temporada, finados, o texto revelou, nas palavras de Corrêa, "que já não somos mais vingativos como o jabuti, mas estamos em 2011 a acreditar nos sinais. Colhendo palavras do texto de Oswald fez perceber ao público e a nós mesmos os rumos atuais do Oficina Uzyna Uzona" (CORRÊA, 2011). Regente dos coros em seu teatro, como se autodeclarava, o diretor disse que Lima especificava o fenômeno teatral em si e não era fundamentalista.

Mariangela é uma das raras artistas da Crítica. [...] Mariangela é a Crítica Artista, o João Gilberto da Crítica do Teatro Brasileiro. Só cria em seu tempo, não de encomenda. [...] Ela é como João. O que produz nas letras, no jornal, tem a mesma maravilha da visão divina do criador da batida da bossa nova. (Ibid.) 
Dona de natureza discreta em sua circulação no meio cultural, Lima parecia consciente do apelo contido nesse discurso. "Eu sempre tive certo cuidado de não me aproximar muito dos artistas, até por preservação da imparcialidade, porque eles são muito interessantes, seduzem. De fato, o teatro é um mundo muito sedutor" (SANTOS, 2018).

Para Solange Lévesque (apud Féral, 2015, p. 45), "o perigo da crítica (mas também sua grandeza)" está em "tornar a crítica tributária da personalidade do crítico". No tocante à crítica jornalística de Lima, cuja extensa cartografia de uma época foi aqui circunstanciada à gênese e ao desfecho de sua condição de espectadora privilegiada das jornadas do Oficina ${ }^{14}$, é possível constatar que a autora salvaguardou um compromisso deontológico do qual seus escritos são testemunhos. Bem como divisar um programa de crítica a ecoar os pressupostos de Féral para que essa prática inscreva seu "espaço na obra, uma distância entre o espetáculo e o espectador, entre a recepção e seu tratamento pelo pensamento" (FÉRAL, 2015, p. 50). A pesquisadora reivindica que:

\begin{abstract}
É preciso, pois, que o crítico reassuma com toda urgência sua responsabilidade social e sua função estética. Utilizando sempre com circunspecção sua subjetividade e explorando o espectro completo do saber, que vai da reação epidérmica aos espetáculos até as análises mais aprofundadas, é preciso que ele efetue a ligação entre emoção e conhecimento, tendo consciência que escreve a história ao delinear o traçado do futuro. (Ibid., p. 51)
\end{abstract}

Modulações presentificadas na fortuna crítica do Teatro Oficina Uzyna Uzona e pinçadas do trabalho de Lima. Da "guerrilha artística", como a montagem de Gracias, señor, foi definida pela integrante do núcleo de pesquisa e curadoria do Instituto Tomie Ohtake, Luise Malmaceda, na exposição-ensaio Al-5 50 anos - Ainda não terminou de acabar, à "felicidade guerreira" (LIMA, p. 2004, p. D7), como a crítica de O Estado de S. Paulo observou a propósito de $O$ homem II: da revolta ao trans-homem, terceira parte do ciclo Os sertões, Mariangela Alves de Lima navegou por conhecimentos, percepções, afetividades e circunstâncias históricas ciente de que "as antenas dos artistas sintonizam o devir enquanto o crítico e o público a quem se dirige a

14 A análise da massa textual oceânica que a crítica produziu será analisada em nosso doutoramento. 
arte estão ancorados no presente" (LIMA, 2005, p. 23). Nesse sentido, transitou o pior momento da ditadura civil-militar, passando por redemocratização, implantação da moeda oficial vigente e governos à esquerda do espectro político. Para quem também desempenhou a atividade de arquivista, secundária mas não menos essencial, a produção de documentos foi exemplar.

\section{Referências bibliográficas}

ARRABAL, J.; LIMA, M. A. O nacional e popular na cultura brasileira: Teatro: o seu demônio é brasileiro. São Paulo: Brasiliense, 1983.

CORRÊA, J. C. M. Má notícia para a história do teatro no Brasil. Blog do Zé Celso, São Paulo, 21 dez. 2011. Disponível em: http://bit.ly/2MSmjKz. Acesso em: 25 jan. 2021. FÉRAL, J. Além dos limites: uma teoria à procura de prática. São Paulo: Perspectiva, 2015.

FONSECA, M. A. Por que ler Oswald de Andrade. São Paulo: Globo, 2008.

LIMA, M. A. Gracias, señor. Estudos Cebrap, São Paulo, n. 2, p. 149-153, 1972.

LIMA, M. A. Perplexidades de um crítico. Arte em Revista, São Paulo, ano 6, n. 8, p. 110-113, 1984.

LIMA, M. A. Oficina invoca Cacilda em tempo de desesperança. O Estado de S. Paulo, São Paulo, Caderno 2, p. D7, 21 nov. 1998.

LIMA, M. A. A crítica teatral. Camarim, São Paulo, ano III, n. 34, p. 22-23, 2005.

LIMA, M. A. Macumba oswaldiana. O Estado de S. Paulo, São Paulo, Caderno 2, p. D10, 2 nov. 2011.

MAGALDI, S. A volta do oficina ou a imagem destruída. Jornal da Tarde, São Paulo, 2 maio 1972.

MAGALDI, S. Depois do espetáculo. São Paulo: Perspectiva, 2003.

MATE, A. Presença de Mariangela Alves de Lima. In: ANUÁRIO de Teatro de Grupo da Cidade de São Paulo. Jundiaí: Maxprint, 2006. p. 9-12.

PEIXOTO, F. (org.). Dionysos: Teatro Oficina, Rio de Janeiro, n. 26, jan. 1982.

ROSENFELD, A. Texto/Contexto I. São Paulo: Perspectiva, 1996.

SANTOS, V. O trabalho da crítica segundo Mariangela. Teatrojornal, São Paulo, 15 jan. 2018. Disponível em: http://bit.ly/3tKSXOE. Acesso em: 28 jan. 2021.

STAAL, A. H. C. (org.). Primeiro ato: cadernos, depoimento, entrevistas (1958-1974). São Paulo: Editora 34, 1998.

STEEN, E. (org.). Amor ao teatro: Sábato Magaldi. São Paulo: Edições Sesc São Paulo, 2014.

Autor convidado 